\title{
METHODS OF SOCIAL REHABILITATION OF CHILDREN AND ADOLESCENTS OF SEXUAL VIOLENCE
}

\author{
${ }^{1}$ G.S. Abdiraiymova , ${ }^{2}$ Sh.K. Tolendi, ${ }^{3}$ Edward Ko-ling Chan
}

\begin{abstract}
This article is devoted to the analysis of various forms of socio-psychological and medical work with children who have been sexually abused. The research article has been done by the collaboration with graduate student and her internal and external scientific advisers as a part of PhD thesis. In the article used modern forms of methods in sociology and social work. The analysis shows that child sexual abuse is one of the most serious and complex problems, involving a variety of inappropriate behavior, including physical and moral components. Research shows that sexually abused children can suffer physical, emotional and psychological consequences, many of which persist throughout their lives. The article describes specific areas of socio-psychological and medical work on the treatment of serious injuries in children who have been sexually abused; the classification of medical and psychological consequences of sexual violence against children was carried out and the relationship between psycho-traumatic effects was revealed. Complex methods of rehabilitation in the study of clinical and psychopathological manifestations in children are considered in detail.

Keywords: child, Sexual Abuse, Trauma, Rehabilitation, Clinical Video, Treatment, Social Rehabilitation, Psychological Trauma, Therapy.

1-2 al-Farabi Kazakh

National University, Almaty, Kazakhstan

3 The Hong Kong Polytechnic University, Hong Kong, China

Author-correspondent:

Sh. Tolendi

kanatovna.sholpan@gmail.com

Reference to this article:

Abdiraiymova G.S.,

Tolendi Sh.K., Edward Ko-ling

Chan. Methods of social rehabilitation of children and adolescents of sexual violence // Adam alemi. - 2021. - No. 3 (89). - P. 111-121.
\end{abstract}

\section{Жыныстық зорлық-зомбылыққа ұшыраған балалар мен жасөспірімдерді әлеуметтік реабилитациялау әдістері}

\begin{abstract}
Аннотация. Бұл мақала жыныстық зорлық-зомбылыққа ұшыраған балалармен әлеуметтік-психологиялық және әлеуметтік жұмыстың әртүрлі формаларын талдауға арналған.Зерттеу мақала докторлық диссертацияның бір бөлігі ретінде докторантпен және оның ішкі және сыртқы ғылыми кеңесшілерімен ынтымақтастықта жасалды. Мақалада әлеуметтану мен әлеуметтік жұмыста заманауи-аралас әдіс түрлері қолданылды.Талдау нәтижелері бойынша, балаларға жыныстық зорлық-зомбылық ең күрделі мәселелердің бірі болып табылады,оның құрамына физикалық және моральдық компоненттерді қоса алғанда, әр түрлі орынсыз мінез-құлық жатады. Зерттеулер көрсеткендей, жыныстық зорлықзомбылық көрген балалар физикалық, эмоционалдық және психологиялық зардаптарға ұшырауы мүмкін, олардың көпшілігі өмір бойы сақталады. Мақалада жыныстық зорлықзомбылық көрген балалардың ауыр жарақаттарын емдеу бойынша әлеуметтік-психологиялық
\end{abstract}


және медициналық жұмыстың нақты бағыттары сипатталған; балаларға қатысты жыныстық зорлық-зомбылықтың медициналық-психологиялық зардаптарын жіктеу жүргізіліп, психотравматикалық әсерлер арасындағы байланыс анықталды. Балалардағы клиникалық және психопатологиялық көріністерді зерттеудегі оңалтудың кешенді әдістері егжей-тегжейлі қарастырылады.

Түйін сөздер: бала, жыныстық зорлық, зақымдану, оңалту, клиникалық бейне, медициналық емдеу, әлеуметтік оңалту, психологиялық зардап, терапия.

\section{Методы социальной реабилитации детей и подростков от сексуального насилия}

Аннотация. Статья посвящена анализу различных форм социально-психологической и медицинской работы с детьми, подвергшимися сексуальному насилию. Статья написана в сотрудничестве с аспирантом и ее внутренними и внешними научными руководителями в рамках докторской диссертации. В статье использованы современные формы методов социологии и социальной работы. Анализ показывает, что сексуальное насилие над детьми - одна из самых серьезных и сложных проблем, включающая целый ряд видов ненадлежащего поведения, включая физические и моральные компоненты. Исследования показывают, что дети, подвергшиеся сексуальному насилию, могут страдать от физических, эмоциональных и психологических последствий, многие из которых сохраняются на протяжении всей их жизни. В статье описаны конкретные направления социально-психологической и медицинской работы по лечению серьезных травм у детей, подвергшихся сексуальному насилию; проведена классификация медико-психологических последствий сексуального насилия в отношении детей и выявлена взаимосвязь между психотравмирующими эффектами. Подробно рассмотрены комплексные методы реабилитации при изучении клинико-психопатологических проявлений у детей.

Ключевые слова: ребенок, сексуальное насилие, травма, реабилитация, клиническое видео, лечение, социальная реабилитация, психологическая травма, терапия.

\section{Introduction}

The total number of children and adolescents who has been attack of sexual violence vary depending on the definitions used and the method of data collection. According to international studies, which has been conducting since 1980, the average level of sexual violence in childhood is $20 \%$ for women and 5-10\% for men.According to D. Finkelhor's study [1], there are significant differences in the prevalence of sexual violence against children between different countries,from 6 to $66 \%$ in women and from 3 to $33 \%$ in men. Malkina-Pykh's work gives even higher figures [2], according to her work $30-90 \%$ of women are victims of sexual violence out of all. At the same time, $1 / 3$ of the rapists are children and teenagers under 16 years old. Louis Harris found out that $89 \%$ of girls and $76 \%$ of boys were sexually abused during their school years. Theoretically, one of the first definitions of sexual violence against children was that «involving sexually dependent, underdeveloped children and adolescents is incapable of fully understand its meaning and process takes place out of their will».American physician $\mathrm{H}$. Kempe defines sexual violence against children as "involving functionally immature children and adolescents in their sexual activities without fully understanding them, disagreeing, or disrupting the social success of family roles". American researchers consider child sexual abuse (CSA) to be any sexual experience with a child under the age of 16 (according to some sources, under the age of 18) and with a person at least 5 years older than the child [4].

The purpose of the study is to identify the clinical and age characteristics of mental disorders in children affected by domestic and extracurricular sexual violence and to develop the basics of medical, psychological and social correction in order to rehabilitate into society. 


\section{Methodology}

In this research work used modern methods of scientific research, including theoretical and empirical research methods. A review of the literature in various fields of science, such as sociology, pedagogy, medicine, psychology. Many scientific articles, textbooks and Internet resources related to the research topic were reviewed using the content analysis method. In the practical part of the study, in order to determine the methods of psychotherapy and psychocorrection of children who have experienced sexual violence in early and preschool age, the method of observation was conducted in the «Scientific Center for Mental Health».

The following questions were asked during the research:

- To determine the psychological and social image of children who are victims of sexual violence;
- Identification of a set of drug methods in medical and psychological work for children;

- Development of a set of somatic complaints in children;

- Analysis of a set of therapeutic methods.

Non-drug methods included social psychotherapy and psychocorrection and were performed in all patients. Physiotherapy and spa vacations were considered for children and families of children who have been sexually abused. The method of psychotherapy and psycho-correction of children who have experienced sexual violence in early and preschool age is adapted for use in children who have been sexually abused by the Scientific Center for Mental Health.

General psychiatric treatments include different groups of drugs (see Table 1).

Table 1 - Medicinal methods of complex medical and psychological work with children victims of sexual violence

\begin{tabular}{|c|c|c|c|}
\hline Group of drugs & $\begin{array}{c}\text { Duration of treat- } \\
\text { ment (months) }\end{array}$ & Dosage of the drug & $\begin{array}{c}\text { Number of treated } \\
\text { patients }\end{array}$ \\
\hline \multicolumn{3}{|c|}{ Sedatives } \\
\hline $\begin{array}{c}\text { Atarax, } \\
\text { Midocalm } \\
\text { seduxen, }\end{array}$ & $1-2$ & Adulthood & 63 \\
\hline $\begin{array}{c}\text { Azafen, amitriptyline, } \\
\text { anafranil, deprim, imipra- } \\
\text { mine }\end{array}$ & $1-3$ & Adulthood & \\
\hline $\begin{array}{c}\text { Antidepressants } \\
\text { Halerianachel, memo- } \\
\text { ria, nervochel, tenoten, } \\
\text { coenzyme compositum, } \\
\text { cerebrum compositum }\end{array}$ & $1-3 \quad$ Adulthood & All \\
\hline $\begin{array}{c}\text { Homic } \\
\text { Rooted }\end{array}$ & All \\
\hline $\begin{array}{c}\text { Vasalamin, Cavinton, } \\
\text { Fezam, Cinnarizine }\end{array}$ & $1-2 \quad$ Adulthood & All \\
\hline \multicolumn{2}{|c|}{ Vitamins } \\
\hline $\begin{array}{c}\text { Multivitamin complexes } \\
\text { (group B, etc.) }\end{array}$ & $1-2$ & Adulthood & \\
\hline
\end{tabular}


These principles include: complexity («break continuity») - the involvement of a number of specialists and even services in the organization of simultaneous assistance to the child and family; systematization («child-family-society») consists of psychotherapeutic and psycho-correctional work not only with the child, but also with the micro-social system - the family. Attention was also paid to the interaction of the microsocial system with the macrosystem - the family, society, social institutions of child support. Thus, the child was helped without interfering with his environment, parents and relatives were involved at the same time; stages («longitudinal continuity») - it is clear that help is needed immediately after stress, which can lead to injury, incidents or violence. It is important that this aspect of assistance is only the first stage. After the first stage, the next stage of care will be needed - rehabilitation, often with the continuation of psycho-correctional and psychotherapeutic measures; the individuality of the approach arising from the mental state of the patient and the circumstances of the situation. In this case, the following were taken into account: the patient's condition and circumstances of the situation, the characteristics of the child's personality and psyche - the level and adequacy of the age of the identity card; composition and personal qualities of parents, siblings, other family members and their relationship; identify the causes of stress («How did it happen?»); features of the plot of the situation (traumatic event).

The main important aspect of theorizing sexual abuse as violence, physical force is not always used in rape, and bodily injury is not always a consequence of it. It is generally known that rape can be fatal, but the prevalence of such cases varies from country to country. The most common consequences of sexual violence are related to reproductive capacity, mental health, and social well-being. The conse- quences of rape can be pregnancy, but the proportion of such cases varies depending on the prevalence of contraceptives in different places and especially barrier use. A study of teenage girls in Ethiopia found that $17 \%$ of those who reported rape were pregnant [5]. This figure corresponds to $15-18 \%$ of rapes from the crisis center in Mexico. A longitudinal analysis in the United States, which observed more than 4,000 women over three years, found that $5.0 \%$ of all rapists between the ages of 12 and 54 nationwide became pregnant. In many countries, raped women are forced to give birth or risk their lives through unprofessional abortions. The practice of violence at an early age reduces a woman's ability to control her sexual life. A teenage girl who is forced to have sex is less likely to use condoms or other contraceptives in the future, which increases her chances of becoming pregnant [6]. A study of factors influencing adolescent pregnancy in Cape Town, South Africa, found that forced onset of sexual intercourse was the third most common factor influencing the frequency of sexual intercourse and the use of modern contraceptive]. Forced sexual intercourse can also lead to unwanted pregnancies in adult women. A survey of married couples in India found that men who forced their wives to have sex caused 2.6 times more pregnancies than non-violent men [7 ].

Authors found that gynecological complications are associated with forced sexual intercourse. These include vaginal bleeding or infections, fibroids, loss of sexual desire, genital irritation, pain during sex, chronic pain in the pelvic region, and inflammation of the urinary tract. Women who have been physically and sexually abused by close partners are more likely to develop health problems than those who have experienced physical violence alone. Sexually Transmitted Infections HIV and other sexually transmitted diseases may be the result of rape. A study of women in shelters

\section{$114 \mid \begin{aligned} & \text { АДАМ ӘЛЕМІ } \\ & \text { №3 (89) 2021, қыркүйек }\end{aligned}$}


found that those who witnessed physical and sexual abuse by close partners were more likely to suffer from sexually transmitted diseases [8]. Women trafficked for sex are particularly at risk for HIV and other sexually transmitted diseases.

\section{Main part}

Sexual violence leads to mental health and behavioral problems in adolescence and adulthood. In one country study, 33\% of women who experienced sexual violence had symptoms of mental illness, $15 \%$ of women who experienced physical violence with a sexual partner, and $6 \%$ of women who did not experience violence [9]. Intimate partner sexual violence exacerbates the mental effects of physical violence.

Women who report forced sex have a significantly higher risk of depression and post-traumatic stress disorder than women who do not have such experience. Post-traumatic stress disorder A study of adolescents in France found a link between rape and sleep disorders, depressive symptoms, somatic complaints, smoking, and behavioral problems (such as violence, theft, and school loss). In the absence of counseling on rape, the psychological side effects persist for at least a year after the injury, and physical health problems begin to decrease during this period. However, up to $50 \%$ of women still have symptoms of stress after counseling [10].

\section{Suicidal behavior}

Women who have experienced sexual violence in childhood or adulthood are more likely than other women to attempt suicide or suicide. This relationship is maintained taking into account age, education, post-traumatic stress disorder and mental illness. The practice of rape or sexual harassment can lead to suicide in adolescence. In Ethiopia, 6\% of schoolgirls who were raped reported attempted suicide [11]. A study of adolescents in Brazil found that the prevention of sexual violence pre- dicted unhealthy behaviors, including suicidal thoughts and actions [12].The experience of severe sexual violence can lead to emotional distress and suicidal behavior. A study of adolescent girls in Canada found that $15 \%$ had suicidal behaviors in the last 6 months of the study [13].

Individual approaches, for instancepsychological assistance and support counseling, treatment and support groups for victims of sexual violence are useful, especially when there are complications associated with the violence itself or the rehabilitation process. There is some evidence that a short-term cognitive-behavioral program that begins immediately after the victim's attack may accelerate wound healing. As mentioned above, victims of sexual violence sometimes blame themselves for what happened, so psychological guilt is also important for recovery from guilt. However, short-term counseling and treatment programs after sexual violence still require further evaluation.

Psychological support for survivors of sexual violence is provided mainly by non-governmental organizations, in particular, crisis centers for victims of rape and various women's organizations. Of course, these services are available to a small number of victims of sexual violence. You can set up hotlines to increase free access. In South Africa, for example, the Stop Child Abuse hotline responded to 150,000 calls in the first 5 months of operation [14]. It is important to focus on combating sexual violence based on health care.

\section{Medical and legal services}

In many countries, the health care system is required to collect medical and legal data to confirm victims' reports or to help identify perpetrators of violence. Studies in Canada have shown that legal and medical records can increase the likelihood of arrest, prosecution and punishment of the perpetrator [15]. For example, one study found that documented physical injury, especially moderate to severe, led 
to accusations that the patient was an acquaintance or close partner, regardless of income level and that he or she knew the attacker. However, studies of children hospitalized after rape in Nairobi, Kenya, show that in many countries, victims of rape are not examined by a gynecologist or an experienced police officer, and there are no standard protocols and guidelines for this [16].The use of standard protocols and guidelines, as well as the collection of evidence, can significantly improve the quality of treatment and psychological support for victims of violence. Procedures for examining children who have been victims of sexual violence should include: a detailed description of the case, along with all the evidence gathered; registration of the victim's history of gynecological diseases and contraceptives used by her; standard record of the results of a complete physical examination; pregnancy risk assessment; testing for sexually transmitted diseases, including HIV testing and treatment; provision of emergency contraception or - if permitted by law; abortion counseling; psychological support and referral to a specialist.In some countries, the protocol is part of a «collection of evidence of sexual violence», which includes instructions and folders for data collection, legal forms and documents for recording experiments. Research itself is often stressful for victims of violence. Showing a video explaining the entire procedure prior to the study significantly reduces this stress.

\section{Training for medical staff}

All health care workers, including psychiatrists and counselors, should undergo in-service training and initial training on issues related to sexual violence. Most importantly, such training should educate health workers about sexual violence and identify and address cases of violence in a gentle but effective manner. It is also important to reduce the incidence of sexual assault in the health care system, which is an important but unexplored problem.
In the Philippines, "task mission" has developed a program to empower the social sciences and reproductive health, which includes doctors, nurses and sociologists and is supported by the Ministry of Health. She has developed teaching models on gender-based violence for nurses and medical students. The objectives of this program are as follows [17]: to address gender and other social aspects of cultural understanding of the roots of violence; identification of high-risk situations of violence in the family and at home, where appropriate; initial measures in cooperation with other specialists; secondary measures, such as identifying victims of violence, training them in basic legal procedures and methods of presenting evidence, referring victims for counseling and supervision, and assisting victims to integrate into society.

These trainings are included in the curricula of both nurses and doctors. Eleven stages of training in the nursing curriculum are divided into four-year training, and in the curriculum of doctors for the last three years in practical classes. Among the forms of correction of mental disorders and psychological problems in children after sexual violence should be noted: regime-organizational measures; methods of drug treatment (including general pediatric and general psychiatrist).

Regulatory and organizational measures are reflected in the necessary, frequent coercive separation of the child, while maintaining a cohesive relationship with the rapist, as well as the organization of professional supervision of the victim by law enforcement and social security agencies. These include measures to correct the effects of unsatisfactory care (diet therapy, nursing, hygiene training), general treatment, vitamin therapy and herbal medicines. Phytotherapy is the most effective for mental disorders, the severity of which is limited to affective disorders.In this case, it was necessary to determine the duration 
of the case of sexual violence; The nature of abuse - rape, pampering, voyeurism, coercion of a child to sexual intercourse with his own body, the body of the rapist, etc. based on the needs of the whole family. The first need, the purpose of psychotherapeutic and psycho-correctional measures - to ensure the further safety of the child, to prevent recurrence in the initial, primary scenario and re-injury in the secondary scenario - careless or worse, targeted use of the situation with the child - adult abuse, ridicule, peers to share. In the case of contact with the rapist, depending on the nature of the case, it was necessary to isolate the victim from the rapist, use professional supervision (often compulsory) and medical and psychological support programs. It is known that the neurotic process develops while maintaining the cause of the disorder. That is, for some reason it is impossible to stop and clear the reactive neurotic state developed without stopping the effects of psychotrauma [18]. Systemic family relationships cannot be avoided, especially to increase the child's safety, protect him or her from repeated abuse, and from all forms of physical, sexual, and psychological abuse. It is clear that the violence determines the failure, the inability of the family as a system to protect the child from the adverse and even catastrophic actions of the environment. Because the child and the family are forced into a therapeutic-correctional process, the family system may oppose participation in therapeutic interventions or even correctional classes by order of a court or other law enforcement agency. Such a reaction can be expressed not only by adults, but also by a child who monitors their conscious or unconscious mood. In this case, the therapeutic and rehabilitation group requires flexibility and spaciousness, freedom of behavioral reactions. The requirement to forcibly bring a child should be avoided. The specialist has the opportunity to visit the child at home with game, art and sensory materials.
Types of psychotherapy are divided into active (art therapy, fairy tale therapy, game therapy, playing with sand, cereals and water) and passive (dry pool, sensory room). The set of psychotherapeutic activities is divided into three main groups: activities aimed at the affected child; parent-oriented activities, parent-child relationships and family-oriented approaches; Finally, psychotherapeutic measures aimed at the perpetrator. Once the fact of sexual violence is identified, the child should be repeatedly protected from stressful situations. First of all, it is the release of the child from a dangerous or unprotected environment.

The second direction was family approaches. Their main goal was to identify and correct the features of the family system that allowed sexual violence. Then "why? How did it happen? How to avoid? ", As well as correcting the causes of neglect and child care errors of all family members, renunciation of the convention, subordination and domination of individual family members (often with antisocial symptoms) and refusal to consider and distrust the child's situation, complaints and opinions. , therapeutic measures should help to create a favorable atmosphere in the family for the recovery and recovery of the child during the stay in the family, to correct the existing psychosomatic disorders, as well as to create conditions for long-term psychotherapy. The scope and nature of child-centered activities will depend on the child's level and form of awareness and sexual background [19].

The degree of reflection of the abuse in the child's mind ranges from a complete lack of understanding of the nature of the actions taken with him, to the inseparability of criminal activities with the child from other internal relationships with an adult.

\section{Research results}

The results of a study conducted at the Research Center for Mental Health in Al-

https://adamalemijournal.com

ISSN 1999-5849 
maty can be analyzed as rehabilitation centers in order to identify forms of socio-psychological and medical work with early and preschool children exposed to sexual violence. On average, the examined children underwent 10 sessions of psychotherapy and psychocorrection. The results of the work were assessed at the clinical, neurological and psychological levels, as well as with the help of special questionnaires of patients' relatives. A positive result was observed in $80 \%$ of cases, in $16 \%$ of cases there were no changes in the condition of the child, and in $4 \%$ of cases the condition of children worsened slightly. This was due to the persistence of conflict situations and the tense emotional situation in the families of these children, as well as insufficient cooperation of the family with the team of psychotherapeutic and psycho-correctional assistance, refusing to attend therapeutic classes. The following are indicators of somatic complaints in children of younger age groups who are subject to domestic and extramarital violence before and after medical and psychological correction (see Tables 1 and 2; Figures 1 and 2).

Table 2 - Somatic (human body) complaints in children victims of domestic sexual violence before and after medical, social and psychological correction

\begin{tabular}{|l|c|c|c|c|}
\hline & $\begin{array}{c}\text { Children under } \\
\mathbf{3} \text { years of } \\
\text { age (before } \\
\text { treatment) }\end{array}$ & $\begin{array}{c}\text { Children } \\
\mathbf{3 - 6} \text { years } \\
\text { old (before } \\
\text { treatment) }\end{array}$ & $\begin{array}{c}\text { Children } \\
\text { under 3 years } \\
\text { of age (after } \\
\text { treatment) }\end{array}$ & $\begin{array}{c}\text { Children 3-6 years } \\
\text { old (after treat- } \\
\text { ment) }\end{array}$ \\
\hline Enuresis & 42 & 39 & 15 & 16 \\
\hline Encopresse & 7 & 5 & 0 & 0 \\
\hline Sleep disorders & 55 & 60 & 42 & 43 \\
\hline $\begin{array}{l}\text { Violation of appetite } \\
\text { for food }\end{array}$ & 33 & 35 & 29 & 17 \\
\hline Headache & 19 & 21 & 15 & 16 \\
\hline Nausea & 52 & 54 & 29 & 30 \\
\hline
\end{tabular}

Table 3 - Somatic complaints in children who have suffered from a group of sexual violence outside the family before and after medical and psychological correction

\begin{tabular}{|l|l|l|l|l|}
\hline $\begin{array}{c}\text { Somatic (concerning } \\
\text { human body parts) } \\
\text { complaints }\end{array}$ & $\begin{array}{c}\text { Children under } \\
\mathbf{3} \text { years (before } \\
\text { treatment) }\end{array}$ & $\begin{array}{c}\text { Children aged } \\
\mathbf{3 - 6} \text { (before } \\
\text { treatment) }\end{array}$ & $\begin{array}{c}\text { Children } \\
\text { under 3 } \\
\text { years (after } \\
\text { treatment) }\end{array}$ & $\begin{array}{c}\text { Children } \\
\text { aged 3-6 } \\
\text { years (after } \\
\text { treatment) }\end{array}$ \\
\hline Enuresis & 27 & 25 & 10 & 9 \\
\hline Encopres & 6 & 7 & 0 & 2 \\
\hline Sleepdisorders & 63 & 65 & 43 & 39 \\
\hline Anorexia nervosa & 24 & 23 & 15 & 11 \\
\hline Headace & 32 & 34 & 10 & 7 \\
\hline Nausea & 40 & 39 & 23 & 25 \\
\hline
\end{tabular}


As can be seen from the tables and figures above, after a comprehensive medical and psychological work in children who have been sexually abused, not only psychological indicators, but also the associated somatic indicators have changed. Thus, in both groups of children after psychocorrection, there is a significant improvement in sleep, as well as in the group of children aged 3-6 years, anorexia, nausea and headache. Encopresis disappeared, the frequency of enuresis decreased. In addition, positive dynamics was observed in both age groups of children [20].

The tables above show indicators of the level of formation, psychophysical development and behavior of children exposed to various forms of violence before and after medical and psycho-correctional work (see Tables 2). The results of the CAT analysis of the emotional characteristics of preschool children in relation to relatives outside the family and domestic violence confirm the data of clinical assessment of the mental state of children. It is important to keep in mind that sexual abuse of young children, especially domestic violence, has serious, barely treatable psychopathological consequences.

At the same time, as a result of psychotherapeutic and psycho-correctional work, the overestimation of the sexual content of the game decreased, the share of role-playing games in other areas increased, and aggression was smoothed. The children were patient. They have reduced backgrounds of fear, apathy, anedonia, and depression. The quality of love for family has improved. In addition, indicators such as isolation and some fears in dealing with unfamiliar adults remained unchanged or unchanged. Excessive mistrust and willingness to communicate with other people also remained unchanged, reflecting the tactics of corrective action aimed at increasing the child's sense of security. The indicator of mental retardation in children has changed slightly (the changes are not statistically significant).

\section{Conclusion}

In early and preschool children who have been sexually abused, it can be concluded that corrective measures are a set of social, medical and psychological measures taken in accordance with the above principles, especially taking into account all psychodiagnostic information. effective, in particular, for anxiety, depression and behavioral symptoms. However, comparing the effectiveness of developed and tested corrective measures with the experience of using existing methods in science, we can conclude that there is no method or set of methods to restore the child's psyche after sexual abuse. abuse of the previous state. That is, despite the development of methods of correction and treatment of these violations, sexual violence, violence, and dirty deeds with young children remain one of the most serious criminal acts in accordance with their public resonance, and the goal of society is to eliminate them completely.

\section{References}

1 Антропов Ю.Ф. Фитотерапия психических расстройств / Ю. Ф. Антропов. - М.: ДеЛи принт, - 2009. - 468 с.

2 Голубева Н.И. Депрессивные расстройства в младенческом и раннем детском возрасте: автореф. дис. канд. мед. наук: Голубева Наталья Ивановна. - М., 2010. - 26 с.

3 Догадина М.А. Сексуальное насилие над детьми. Выявление, профилактика, реабилитация потерпевших / М.А. Догадина, Л. О. Пережогин // Вопросы ювенальной юстиции. - 2007. - № 4 (13). - С. 10-16.

4 Finkelhor D. Child Sexual Abuse: New Theory and Research / Finkelhor D. - New York: The Free Press. -2013.

5 Малкина-Пых И.Г. Психология поведения жертвы: Справочник практического психолога / И.Г. Малкина-Пых. - М.: Эксмо, 2006. -108 c.

6 Сафуанова О.В. Правовые аспекты проблемы «сексуального злоупотребления» в отношении детей / О.В. Сафуанова // Группо- 
вая психотерапевтическая работа с детьми, пережившими сексуальное насилие / Пер. с англ. А. В. Байгузова. - М.: «Генезис», 2015. C. 12-15.

7 Шимонова Г.Н. Вегетативный статус и его особенности у детей раннего возраста из группы высокого риска по шизофрении: автореф. дис. ... канд. мед. наук: Шимонова Галина Николаевна. - М., 2013. - 26 с.

8 Шевченко Ю.С. Онтогенетически ориентированная психотерапия (методика ИНТЭКС): Практ. пособие / Ю.С. Шевченко, В. П. Добридень. - М.:, Российское психологическое общество, 2014. - 157 с.

9 Anteghini $\mathrm{M}$ et al. Health risk behaviors and associated risk and protective factors among Brazilian ado- lescents in Santos, Brazil. Journal of Adolescent Health, 2001, 28:295-302.

10 Briggs $L$, Joyce PR. What determines post-traumatic stress disorder symptomatology for survivors of childhood sexual abuse? Child Abuse \& Neglect, 2003, 21:575-582

11 Boyer D, Fine D. Sexual abuse as a factor in adolescent pregnancy. Family Planning Perspectives, 2014, 24:4-11.

12 Bagley C, Bolitho F, Bertrand L. Sexual assault in school, mental health and suicidal behaviors in adolescent women in Canada. Adolescence, 2011, 32:361-366.

13 Carpeta de informacion basica para la atencion solidaria y feminista a mujeres violadas. [Basic informa- tion file for mutually supportive feminist care for women rape victims.] Mexico City, Centro do Apoyo a Mujeres Violadas, 2010.

14 Campbell JC, Soeken K. Forced sex and intimate part- ner violence: effects on women's health Violence Against Women, 2006, 5:10171035.

15 Creamer M, Burgess P, McFarlane AC. Post-traumatic stress disorder: findings from the Australian National Survey of Mental Health and Well-being. Psychological Medicine, 2001, 31:1237-1247.

16 Cheasty M, Clare AW, Collins C. Relation between sex- ual abuse in childhood and adult depression: case-control study. British Medical Journal, 2003, 316:198-201.

17 Choquet $M$ et al. Self-reported health and behavioral problems among adolescent victims of rape in France: results of a crosssectional survey. Child Abuse \& Neglect, 2009, 21:823-832.

18 Christofides N. Evaluation of Soul City in partnership with the National Network on
Violence Against Child (NNVAC): some initial findings. Johannesburg, Child's Health Project, University of the Witwatersrand, 2000.

19 Chaudhry $S$ et al. Retrospective study of alleged sexual assault at the Aga Khan Hospital, Nairobi. East African Medical Journal, 2004, 72:200-202.

20 Darves-Bornoz JM. Rape-related psychotraumatic syndromes. European Journal of Obstetrics, Gynecology and Reproductive Biology, 2005, 71:59-65.

\section{Transliteration}

1 Antropov Yu. F. Fitoterapiya psikhicheskikh rasstrojstv [Herbal medicine for mental disorders] /. - M.: DeLi print, - 2009. - 468 s. (in Russ)

2 Golubeva N.I. Depressivny`e rasstrojstva $v$ mladencheskom i rannem detskom vozraste [Depressive disorders in infancy and early childhood]: avtoref. dis. kand. med. nauk:a. - M., 2010. - 26 s. (in Russ)

3 Dogadina M.A. Seksual'noe nasilie nad det’mi. Vy'yavlenie, profilaktika, reabilitacziya poterpevshikh [Child sexual abuse. Identification, prevention, rehabilitation of victims] // Voprosy`yuvenal'noj yusticzii [Issues of juvenile justice]. - 2007. - \# 4 (13). - S. 10-16. (in Russ)

4 Finkelhor D. Child Sexual Abuse: New Theory and Research / Finkelhor D. - New York: The Free Press. -2013.

5 Malkina-Py'kh I.G. Psikhologiya povedeniya zhertvy: Spravochnik prakticheskogo psikhologa [Psychology of victim behavior: Handbook of the practical psychologist] /. - M.: E’ksmo, 2006. - 108 s. (in Russ)

6 Safuanova O.V. Pravovy`e aspekty problemy` "seksual'nogo zloupotrebleniya» v otnoshenii detej [Legal aspects of the problem of "sexual abuse" of children] / Per. s angl.. - M.: «Genezis», 2015. - S. 12-15. (in Russ)

7 Shimonova G.N. Vegetativny j status i ego osobennosti u detej rannego vozrasta iz gruppy vy`sokogo riska po shizofrenii [Vegetative status and its features in young children at high risk for schizophrenia]:. - M., 2013. - 26 s. (in Russ)

8 Shevchenko Yu.S. Ontogeneticheski orientirovannaya psikhoterapiya (metodika INTE'KS): Prakt. Posobie [Ontogenetically oriented psychotherapy (INTEX method)] / - M:, Rossijskoe psikhologicheskoe obshhestvo [Russian Psychological Society], 2014. - 157 s. (in Russ) 
9 Anteghini $M$ et al. Health risk behaviors and associated risk and protective factors among Brazilian ado- lescents in Santos, Brazil. Journal of Adolescent Health, 2001, 28:295-302.

10 Briggs L, Joyce PR. What determines post-traumatic stress disorder symptomatology for survivors of childhood sexual abuse? Child Abuse \& Neglect, 2003, 21:575-582

11 Boyer D, Fine D. Sexual abuse as a factor in adolescent pregnancy. Family Planning Perspectives, 2014, 24:4-11.

12 Bagley C, Bolitho F, Bertrand L. Sexual assault in school, mental health and suicidal behaviors in adolescent women in Canada. Adolescence, 2011, 32:361-366.

13 Carpeta de informacion basica para la atencion solidaria y feminista a mujeres violadas. [Basic informa- tion file for mutually supportive feminist care for women rape victims.] Mexico City, Centro do Apoyo a Mujeres Violadas, 2010.

14 Campbell JC, Soeken K. Forced sex and intimate part- ner violence: effects on women's health Violence Against Women, 2006, 5:10171035.

15 Creamer $M$, Burgess $P$, McFarlane AC. Post-traumatic stress disorder: findings from the Australian National Survey of Mental Health and Well-being. Psychological Medicine, 2001, 31:1237-1247.

16 Cheasty M, Clare AW, Collins C. Relation between sex- ual abuse in childhood and adult depression: case-control study. British Medical Journal, 2003, 316:198-201.

17 Choquet $M$ et al. Self-reported health and behavioral problems among adolescent victims of rape in France: results of a crosssectional survey. Child Abuse \& Neglect, 2009, 21:823-832.

18 Christofides N. Evaluation of Soul City in partnership with the National Network on Violence Against Child (NNVAC): some initial findings. Johannesburg, Child's Health Project, University of the Witwatersrand, 2000.

19 Chaudhry $S$ et al. Retrospective study of alleged sexual assault at the Aga Khan Hospital, Nairobi. East African Medical Journal, 2004, 72:200-202.

20 Darves-Bornoz JM. Rape-related psychotraumatic syndromes. European Journal of Obstetrics, Gynecology and Reproductive Biology, 2005, 71:59-65.

\section{INFORMATION ABOUT AUTHORS}

\section{Gulmira Abdiraiymova}

Sholpan Tolendi

Edward Ko-ling Chan

Гулмира Сериковна Абдраймова

Шолпан Канатовна Төленді

Эдвард Ко-линг Чан

Гулмира Сериковна Абдраймова

Шолпан Канатовна Төленді

Эдвард Ко-линг Чан
Doctor of Social Sciences, Professor, al-Faraby Kazakh National University, Almaty, Kazakhstan

PhD candidate, al-Faraby Kazakh National University, Almaty Kazakhstan

Professor, Hong Kong Polytechnic University, Hong Kong, China.

Әлеуметтану ғылымдардың докторы, профессор, әлФараби атындағы Қазақ ұлттық университеті, Алматы, Қазақстан

PhD докторант, әл-Фараби атындағы Қазақ ұлттық университеті, Алматы, Қазақстан

Гонконг политехникалық университетінің профессоры, Гонконг, Қытай

Доктор социалологических наук, профессор, Казахский национальный университет имени аль-Фараби, Алматы, Казахстан

$\mathrm{PhD}$ докторант, Казахский национальный университет им. Аль-Фараби, Алматы, Казахстан

Профессор, Гонконгский политехнический университет, Гонконг, Китай 